\title{
OF RACE AND MAN: RECONSTRUCTING CITIZENSHIP AND THE NATION IN ABDULLAH HUSSAIN'S INTERLOK
}

Ahmad Thamrini Fadzlin Syed Mohamed thamrini@upnm.edu.my

Centre for Liberal and Language Studies Universiti Pertahanan Nasional Malaysia

Noraini Md. Yusof animy@ukm.my

Ruzy Suliza Hashim ruzy@ukm.my

Faculty of Social Sciences and Humanities Universiti Kebangsaan Malaysia

\begin{abstract}
This paper attempts to provide an alternative perspective of Abdullah Hussain's Interlok (2010) by examining the original version of the novel published in 1971. Exploring the controversy through claims made by the general public, academics and experts through the Internet, we argue that those who found the novel racist in essence are themselves guilty of racism. The
\end{abstract}


paper will further suggest that Abdullah Hussain is a fierce nation builder who attempts to redefine the nation's idea of citizenship and nationhood that can be explained by using the Race Relations Cycle theory. Most importantly, the article demonstrates the writer's desire to try and redefine citizenship among the Malaysian people by deconstructing well-perceived stereotypical race constructions and promoting unity in a new nation.

Keywords: Interlok, racism, nationalism, Abdullah Hussain

\section{Introduction}

Since the introduction of the abridged student version of Interlok (2010) by Abdullah Hussain as a literature textbook for Form Five students, many Malaysians have argued over its usage. Even though the Ministry of Education has reasoned that the novel was chosen due to its "1Malaysia" content, many still opposed its inclusion as a compulsory text because it advocates Malay superiority. An event on January 8, 2011 in Klang, Selangor where protestors, especially those from the Indian community, burned the novel and the picture of the writer are evidence of the strong feeling of resentment against the novel. Although the issue has been amicably resolved by the deletion of certain words deemed racist by the action committee which has been entrusted to make the text appealing to the general public, it is imperative to revisit the controversy. This is crucial, and this paper will go on to argue that the controversies over the novel are shrouded by the prejudice and bad politics of certain groups of people that may affect the general public's opinion of the novel. Nevertheless, despite the huge amount of brief yet critical writings about the novel available on the Internet, none has made an extensive analysis of the novel or has delved into the real issues presented by the writer.

This paper attempts to fill this gap by examining the original novel published in 1971 while the English excerpts used in this article are from the translated version of the novel published in 2010. Through this, we hope to further demystify the "honest" analysis of the novel made by others using the original text itself. In other words, this paper is not particularly concerned to search for the "truth" portrayed by the writer within the period under study. Rather, the discussion is focused on the invention and suppression of the "truth" by the critics, hence attempting to 


\section{MALAY LITERATURE}

provide an alternative view of the novel intended by the writer. The first section examines the controversies and criticisms both for and against the novel. This is followed by a critical analysis of the novel which depicts the formation of a nation by its members manifested by the writer using Robert E. Park's Race Relations Cycle as presented by Feagin and Feagin (1999). Most importantly, in the discussion that follows, we attempt to argue that Abdullah Hussain's idea of a multiracial society in Malaysia is filled with harmonious relationship between the three main racesMalay, Chinese and Indian-that has been misinterpreted with biases and prejudices. Before going on further, however, we would like to stress that this paper is primarily a study of Interlok's portrayal of race relations and not the superiority of one race over another. Abdullah Hussain's depictions of race relations conveyed through the novel are indeed ahead of his time, as the novel promotes unity and the spirit of standing side-byside to overcome hardship in life.

\section{Interlok: Polemic over Context and Discourse}

Based on the public opinion available through the Internet, it has been determined that the dismissal of Interlok by the Indians and the Chinese can be discussed under five premises. First of all, Indians have claimed that Interlok is said to be degrading, disrespectful and misleading through its depiction of the caste system and the usage of the term "Pariah". Jeyaseelen Anthony (2011) in The Centre for Policy Initiatives portal (http://english.cpiasia.net/) classifies the novel as the most controversial book ever published in Malaysia which should not be used as a text in schools as the book "touches on caste, which in itself is a sensitive and controversial topic even among Indians". Secondly, those who oppose its usage claim that the novel carries within it a recollection of stereotypes of races that undermines other races. Scott Thong (2011) through a website and Hartal MS (2011) through the Malaysia Today portal, for example, describe the novel as a novel that "is filled with every conceivable racial stereotype of Indians and Chinese that you can think of, applied hodgepodge but in overabundance to the main characters". They then prove their points through the characterisation of characters in the novel like Maniam, Ching Huat, Perumal, Meng Hua and many others, and conclude that the novel "successfully" portrays the Indians and the Chinese as "prostitutes, womanisers, gamblers, cheats, scumbags, opium addicts, 
and more". Apart from that, the novel is also seen as promoting the Malay political archetype as it re-enforces the stereotype that the Chinese and the Indians are foreigners and they "must be grateful for the opportunities given by [Malay]sia" (Hartal MSM, 2011). In a report by the Malaysian Mirror, Ng Chong Soon, the Chairman of the Kuala Lumpur and Selangor Chinese Assembly Hall Youth Section is reported as saying that:

\begin{abstract}
Although this novel depicted the era from Japan(ese) Occupation until Malaya gained its independence and how Malays, Chinese and Indians strived for survival during that period, the content of the novel is full of racial discrimination and biasness [sic]. Besides reinforcing the stereotype of Chinese and Indians [as] outsiders and immigrants, Chinese are deceitful and greedy, this novel also unconsciously promotes the idea of Malay supremacy in many of its chapters.
\end{abstract}

(Malaysian Mirror, 2011)

This brings us to the third reason why some have contested the novel, as it is said to portray other races using wrongful information. $\mathrm{K}$. Pragalath (2011) has opined that the text under discussion here "contains factual errors" where he argued that the caste system mentioned in the novel is non-existent and a wrong portrayal of the Indian community of the time. The fourth reason for the call for exclusion of the novel from the education system is due to the fact that it does not adhere to the guidelines of textbook writing, as described by Collin Abraham (2011) through the Malaysia Today portal. Lastly, the opposing party questioned the teacher's capability to teach the novel and suggested that she/he would not be capable of addressing sensitive issues regarding race. Rajendran (2011) and Pragalath (2011) contend that because the majority of teachers teaching Malay Literature are Malays, there is an issue of the teacher's ability to explain the use of controversial words in the proper context, and avoid the usage of such words by the students. The misrepresentations provided in the novel led a number of people, especially from the Indian community, to protest against the novel and demand that Interlok be excluded from schools. An incident that had happened in front of Dewan Sentosa, Majlis Perbandaran Klang, which resulted in the burning of the novel and the novelist's picture (Helmi, 2011) is one of many protests held to show discontent over the matter. 


\section{MALAY LITERATURE}

But, is it true that the novel is delivering or forcing negative ideas and portrayals of other races in Malaysia? Or, to state it more directly, is it true that the novel is racist in nature? Most academics and literary enthusiasts do not believe so as they argue that the novel portrays good moral values such as unity, loyalty and patriotism. The use of capital "P" for "Pariah", according to Teo Kok Seong, linguistically suggests that the word refers to "a social entity in the caste system and is not intended as a generalisation" (Dzulkifli, 2011, Suzieana and Nurjehan, 2011). In addition, Teo further explains that the word is written "in the form of narration-not as part of a dialogue or monologue-which means that it is used to expose a fact about the caste system". This attitude is in line with Johan Jaaffar (2011) who remarks in "Give a fair hearing to Abdullah's 'Interlok" that the word is used twice; "in the first instance, he was mentioning the lead character's position in the caste system; the second, he was amazed at how the caste system was not evident in Malaya". Speaking to the press, Rais Yatim said that the paragraph which has the "Pariah" word in it should be maintained, as a novel should be read and understood in the context of its plots and subplots (Zulkifli, 2011).

On the issue of how Indians are being portrayed in the novel, Suzieana and Nurjehan included in their report that according to Raja Rajeswari Seetha Raman, there are phrases in the book that elevate the Indians, for example, when the Malay protagonist, Seman, calls Maniam "Tuan" out of respect. In "Dusta jika anggap Interlok tidak baik" (Utusan Online, 2011), Lim Swee Tin reportedly said that those who claim that the novel's content is degrading, disrespectful and misleading, are in truth lying to the public. He then added that the novel carries within it an idea of nationhood and nation-building that requires the readers to evaluate the novel through its wisdom and the author's true intention in writing it. On the same note, Chua Soi Lek defended the novel by saying that the novel is not racist but is filled with depictions of the harmonious relationship between races and is aimed at cultivating unity among the people as they share the same history which has taken place during the colonial period (Utusan Online, 2011). Thus, based on the arguments given by both parties, how should we-as readers and the public-react to the issue and the novel?

The different stands and arguments over the validity of the novel as a tool to cultivate unity among the different races in Malaysia suggest the polemic over context and discourse. This also suggests the dangers of writing; the fact is that the writer is dead as his or her work is published 
and at the mercy of the public eye. In answering the core problem to the public acceptance of Interlok, and to determine whether or not it is a racist discourse, the public must understand the true definition of racism and the attributes of a racist. In his book, John Arthur describes racism as "racial contempt in the form of an attitude of either hostility or indifference toward people's legitimate interest in virtue of their race" (2007:15). On the other hand, a racist is a person whose "attitudes include unjustified hostility toward a racial group" (2007:23) "accompanied by character and moral defects" (2007:25) that ultimately result in an act of violence towards a racial group. The significant "character and moral defects" would be that a racist is prejudiced; this can best be described as having "closed mind, violently rejecting any alternative view, refusing to criticize or allow others to criticize his assumptions, read and listened not to learn, but to acquire information and find additional support for prejudices and opinions already in his mind" (John Arthur quoting Allan Bullock, 2007:20).

Based on these definitions, we contend that those who suggested the novel is racist are themselves racists. This is a strong claim, as it accuses someone of being racist, but the allegation is not baseless. By evaluating the available comments and opinions included in the study, it can be concluded that those who oppose the usage of the novel project their own prejudices on it. Hartal MSM (2011) "Interlok: Chinese Sell their Daughters", Collin Abraham (2011) "Withdrawal of Interlok Mandatory" and Scott Thong (2011) "Interlok: Chock Full of Insults" are among many that exemplify such an attitude befitting the definition of a racist provided above. The analyses by Hartal MSM and Scott Thong, for example, provide the reader with textual evidence from Interlok which is used to support their claim that the novel denigrates the Chinese and the Indian people. On the other hand, Collin Abraham argues that the inclusion of the novel is against the textbook guidelines set by the Ministry of Education and Dewan Bahasa dan Pustaka (DBP). Readers should be aware of these critics' voices against the novel and how the arguments made are based on information that magnify their prejudices and opinions which have been already formed in their minds.

Enquiry of the writer's intentions added more questions as their commentary seemed to exclude Chapter Four of the novel, Buku Empat: Interlok. We maintain that Chapter Four is the most significant chapter of the novel as it upholds the agenda of the writer. In fact, the novel's name repeats that chapter's title. Despite this, the situation is worsened 


\section{MALAY LITERATURE}

by the absence of analectic articles made accessible in the media to the general public that discuss the "bigger picture" of the novel and support its use in schools. As mentioned earlier, the novel carries within it ideas of nationhood and nation building in all four chapters which can only be analysed through a reading of all chapters. Furthermore, the fact that all characters have been given an equal voice and space to share their respective stories in the novel is also ignored and misinterpreted. Thus, reading the novel with emphasis on only one of the chapters will derail the readers' understanding of the novel and will produce an analysis that is out of context and departs from the spirit in which the novel was written.

\section{Interlok: Remapping Citizenship and the Nation}

We assert that the novel is an attempt made by the writer to re-map the nation's citizenship and nationhood through its depiction of race and ethnic adaptation, and conflict in Malaya during the period of 1900 to 1957. It is during this time that the whole idea of Malaysian nationalism took shape and came into realisation. This period, which sets the background for the novel, sees the intercultural contact between the Malays and the Chinese and Indian immigrants brought in by the British. By applying concepts proposed by Robert E. Park's Race Relations Cycle as presented by Feagin and Feagin (1999), which are contact, competition, accommodation, and eventual accommodation, we examine the consequences when different people come into contact with one another and are coerced to live together. However, the paper will only discuss the first three stages of the cycle as the last, which involves further assimilation between the immigrants and the native people of the land, is not depicted in Interlok.

At the contact stage, "migration and exploration bring peoples together, which in turn leads to economic competition and thus new social organisation" (Feagin and Feagin, 1999:36). Historically the development of ports in the Straits Settlements in the 1870s created the needs to employ competent workers in the British offices. Peter Wicks (1980) indicated that when Malaya came under the control of the British, the Straits Settlements -Singapore, Malacca and Penang-were to serve as well-located ports and replenishing stations for ships going on the India-China route.

Realising the need to employ competent workers, the British then engaged an education system which according to Abdullah (2007) did not 
cater to the needs for development, character building, national identity, and national unity. Instead of educating the Malayan people as a whole, the education system was used to create loyalty towards the original homeland of the colonisers; this strategy controlled the locals from revolting and suppressed the upsurge of a national spirit. The tactic known as the British "Divide and Rule" policy allowed the British to maintain power over the people and avoid any unwanted insurgence from the people of Malaya.

The success of this policy is evident in Interlok as the situation is captured by Abdullah (1971) through the first three chapters, namely through depictions of Seman's family, Ching Huat's family and Maniam's family. Coming from their respective homelands, China and India, Ching Huat and Maniam struggled to overcome obstacles before settling down in Malaya. Both of them had to leave their country due to their unfortunate living conditions in their own respective countries: Ching Huat experienced failed crops due to attacks from grasshoppers while Maniam was not able to find a job as there were too many people in his home country. Ching Huat and Maniam were described as being closer to their own community and not having much contact with the natives. This situation led them to be caught within the predetermined social structure of colonial Malaya: the Chinese were usually associated with business or mining activities, Indians were estate coolies, while the Malays-through the portrayal of Seman-were village people living their lives as farmers. Abdullah criticises this racial-based social structure in Interlok through Musa who goes to a rubber estate to look for a job:

"Aku tak pikir kebun itu mau menerimanya. Disana semua orang2 kita saja yang bekerja. Dilombong itu pula orang2 China saja. Jaga kebun saja orang Sikh," kata Malabari itu.

("I don't think the estate will take him. Only our people work there. And the mines are owned by the Chinese. Only Sikhs work as guards at the estate," said the Malabari.)

(Interlock, 2010:262)

However, despite this obstacle, Musa manages to get a job at the estate with the help of Maniam, which paves the way for other Malays to work at the estate, as portrayed in the novel. This suggests Abdullah's intention of remapping the colonial construct of race and his vision of a new social 


\section{MALAY LITERATURE}

construct that is not determined by what race they are but rather by what they can do.

The second cycle is competition and conflict as a result of "contacts between host peoples and the migrating groups" (Feagin and Feagin, 1999:36). As the characters embark on their journey in the new country, they are presented with challenges of getting themselves comfortable with their new surroundings. As a result, this creates conflict and competition in terms of defending one's own culture or assimilating to the culture of the natives. When reading Interlok, readers may notice the desire of the Indians and Chinese to keep their community rooted to the land of their ancestors.

Pekan Simpang empat sudah semakin besar...Penduduk2 China yang ada kira2 limabelas keluarga itu merasakan sudah sampai masanya mereka mendirikan sebuah sekolah untuk mengajar anak 2 mereka membacha dan menulis bahasa kebangsaannya. Sekolah2 lain letaknya amat jauh dan tidak ada yang upaya mau menghantar anak-anaknya kesekolah-sekolah itu... Tidak ada seorang pun diantara mereka yang mau menghantar anaknya kesekolah Melayu yang sudah didirikan kerajaan disitu. Mereka mesti mendidik anak2 mereka menurut adat istiadat mereka sendiri, mereka mesti mengingatkan anak2 mereka pada tanah leluhurnya, pada kebudayaannya yang tua, pada bahasanya yang kaya.

(Interlok, 1971:151)

(The town of Simpang Empat grew bigger... The Chinese residents, from about fifteen families, felt it was time to build a school to teach their children how to read and write in their own language. There was another school, but it was far away... Not a single one of them wanted to send their children to the Malay school built by the government. They decided that they had to educate their children according to their customs to remind them of their ancestral home, the old culture and language.)

(Interlock, 2010:183)

“Apakah perlu anak2 itu diberi sekolah?” Tanya orang putih tua itu ketika Perumal datang menyerahkan surat permohonan bersama-sama dengan anggota rombongannya...

"Perlu memang perlu, tuan besar," jawab Perumal. "Kami tidak mau anak2 itu lupa pada Negeri ibu bapanya".

"Hantar saja kesekolah Melayu yang sudah ada itu", kata orang 
putih itu lagi. Sekolah Melayu memang ada di Simpang Empat tak jauh dari Changkat Lima.

"Tetapi itu sekolah untuk orang Melayu saja dan kami tidak mau anak2 kami itu menjadi orang Melayu. Kami mau mereka tetap jadi orang Tamil dan satu hari nanti mereka pulang ke India."

(Interlok, 1971:226)

("Is it necessary to provide a school for the children?" the big boss asked Perumal when he came to hand in the request together with a group of workers...

"It is necessary, sir," Perumal answered. "We do not want these children to forget the country of their parents."

"Just send them to the available Malay schools," the white man said. There was a Malay school in Simpang Empat, not far from Changkat Lima.

"But that school is only for the Malays. We do not want our children to become Malays. We want them to remember they are Indians, and one day, they will return to India." )

(Interlok, 2010:270)

The desire of keeping the Self in touch with the homeland is common in any immigrant community in many parts of the world. The existence of Chinatown or Little Bombay in countries such as Malaysia, the United States and Australia exemplifies the community's self-perseverance towards its own religion, culture and identity. Ching Huat's wedding (pp.145-46) and Maniam's wedding (pp. 184-86) in the original version of Interlok illustrate the immigrants' desire to stay in touch with their homeland through elaborate descriptions of their respective wedding ceremonies. However, the younger generation of immigrants may have problems to reconnect with the land of their ancestors. This situation is also shown in Interlok through Yew Seng, one of Ching Huat's sons:

Malam itu Yew Seng tidak ada ranchangan apa2 ia mengambil buku klasik Shu Ching yang terkenal itu dibachanya. Buku itu sudah lama dipinjam dari kawannya guru sekolah, tetapi ia terlalu malas mau membachanya. Ia lebih senang bertandang kerumah Lazim dan kadang2 belajar membacha bahasa Melayu dari guru itu. Malam ini dia tidak keluar. Ia mau membacha buku klasik ini yang oleh guru muda sekolah China itu dikatakan amat baik. Yew Seng tidak dapat menggambarkan betapa baik 


\section{MALAY LITERATURE}

isi buku yang mengandungi himpunan dokumen 2 sejarah purbakala itu. Ia tahu Negeri asal bapanya amat besar, kebudayaannya amat tinggi tetapi ia tidak pernah sampai kesana, malah dia tidak tahu pun siapa 2 yang masih ada lagi. Hanya kerana ada darah China mengalir dalam tubuhnya saja perasaannya agak tersinggung mendengar penyerangan orang2 Jepun kenegeri China itu, tetapi perasaannya itu tidak mendalam benar, sebab hubungan yang langsung Antara dia dengan Negeri itu tidak ada. Dia lebih dekat dengan orang2 dinegeri ini, kalaupun Lazim itu dipukul orang dia akan merasa seperti dia sendiri dipukul, dia mau berkorban untuk membela Lazim kalau perlu, orang2 Melayu disini baik2 belaka dengan dia kerana dia boleh berchakap-chakap dengan lanchar dengan mereka itu dalam bahasa mereka sendiri.

(Interlok, 1971:161)

(That night Yew Seng had no other plans. He picked up the famous classic, Syu Cing, and started to read. He had borrowed that book sometime ago from his teacher friend but he had been too lazy to read it. He preferred to visit Lazim's house and learn to speak Malay with him. That night, he did not go out. He wanted to read the classic. He knew that his father's country was big and cultured, but he had never been there. In fact, he didn't know if he still had any relatives there. Only the Chinese blood flowing in his veins made him angry with the Japanese, but he was not all that concerned because he had no relationship with China. He felt closer to the people of this country, and if someone attacked Lazim, he would feel as if he was being attacked too. If need be, he would fight to protect Lazim. The Malays around here were good to him because he could speak their language fluently.)

(Interlock, 2010:195-96)

Again in this situation, Abdullah is trying to redirect the idea of citizenship of the nation when he portrays Yew Seng as the generation of the Chinese who see themselves as Malayans born in Malaya. Yew Seng's character represents a generation of Malaysian Chinese who acknowledge themselves as a part of the land, no longer a foreigner or an immigrant from another place. It is important to note here that Yew Seng's portrayal of accepting the Malay language does not mean Abdullah is glorifying Malay superiority. To really understand the writer's intention, one must first understand the growth of nationalism. According to Kohn, nationalism "is the process of integration of the masses of the people into 
a common political form (and) therefore presupposes the existence, in fact or as an ideal, of a centralised form of government over a large and distinct territory" (1944:4). In the case of Interlok, the Malay language has been used as a tool to unite the people of Malaya with a sense of belonging. Thus, in the novel, it is this "process of integration" which is highlighted by Abdullah through the character of Yew Seng. Abdullah does not glorify the Malay language and the Malay people as true masters of Malaya (Malaysia), but rather uses them as symbols of national unity and identity.

The third phase in Park's Race Relation Cycle is accommodation, which involves "a migrating group's forced adjustment to a new social situation which can result to stabilisation of relations" (Feagin and Feagin, 1999:36). This "forced adjustment" can be in the form of imposed rule by the natives or certain events and circumstances that force the races to unite. In the last chapter of Interlok, Abdullah uses the Japanese Occupation as a setting that forces the characters to unite and to set their differences aside to overcome the atrocities brought upon them by the Japanese army. The chapter best depicts a chaotic period, where all the characters in the novel share an equal amount of hardship, torture and maltreatment. Adversity during these times is captured in Interlok:

Keadaan hidup sudah mulai terasa sukar. Semakin lama semakin sempit. Barang2 keperluan amat berkurangan dan yang ada sedikit2 itupun harganya semakin membubung. Keperluan orang lebih banyak daripada persediaan, sehingga untuk itu wang Jepun sangat banyak beredar dalam pasar.

Orang2 kampung juga mulai terchekik hidupnya, hasil pertanian mereka terpaksa dijual kepada Jepun dengan harga murah, kalau tidak mau dijual dirampas dan yang punyanya ditangkap dan dihukum. Nelayan2 juga tidak terlepas dari perbuatan kejam itu, ikan basah yang mereka bawa pulang dari tangkapannya, diambil oleh Jepun dengan harga murah, kalau ketahuan disembunyikan mereka akan ditangkap dan disiksa. Orang2 yang menjadi mata2 Jepun amat banyak, sehingga satu sama lain sudah churiga menchurigai.

(Interlok, 1971:303)

(Life had become more difficult. Essential goods were limited and the prices skyrocketed. Demand far outweighed supply, and because of that too much Japanese money circulated in the market. 


\section{MALAY LITERATURE}

The villagers felt greater hardship. They had to sell their agricultural produce to the Japanese at low prices. If they refused, their goods were seized and they faced arrest. The fishermen were not exempt. The Japanese bought their catch at low prices. If they were found to have hidden their catch, they were arrested and tortured. There were many informers, and people became wary of each other.)

(Interlock, 2010:363)

As situations worsen, Seman, despite his past predicament and discrepancy with Ching Huat, saves Poh Eng (one of Ching Huat's daughters) and hides her in his home with his mother, Mak Limah. The close proximity brings Mak Limah and Poh Eng together, and this is evident when they are reunited after the Japanese reign ends.

Waktu Mak Limah melihat Poh Eng ia sudah lupa bahwa anak perempuan itu seorang bangsa asing, ia terus memeluknya dan menangis terisakisak. Poh Eng juga sudah tidak dapat menahan hatinya lagi. Ia juga ikut menangis.

(Interlok, 1971:315)

(When Mak Limah saw Poh Eng, she hugged her and wept incessantly. Poh Eng too could not contain herself. She began to cry too.)

(Interlock, 2010:377)

The relationship between Mak Limah (Malay) and Poh Eng (Chinese) as a result of the Japanese Occupation clearly suggests Abdullah's idea of a harmonious interracial relationship which stabilises the relationship between the native and the immigrant people. By making these charaters share and overcome the same misery, Abdullah successfully portrays his view and notion of nationalism that encompasses all the people of Malaya without any prejudice concerning skin colour and race. Furthermore, the novel also depicts the spirit of working together as one society to overcome problems. Abdullah expresses this vision at the end of the novel:

Waktu Yew Seng masih dalam rumah sakit beberapa tahun yang lalu, mereka dari pekan itu dan dari kampong sekitarnya telah mengumpulkan 
wang untuk membeli kaki kayu tersebut, tetapi Ching Huat berkeras menolaknya, ia mau membelinya sendiri. Ia ada wang. Ia tidak mau menyusahkan orang ramai kerana anaknya itu. Tetapi Lazim dan Raman pun berkeras pula, mereka mau mereka juga dapat menolong Yew Seng. Keputusan terakhir diserahkan kepada Yew Seng memutuskannya, dan dia memilih kaki kayu yang akan diserahkan oleh masharakat Melayu dan India, masharakat China dipekan itu kemudian ikut sama. Itulah kaki kayu yang digunakan Yew Seng sekarang.

(Interlok, 1971:339-40)

(When Yew Seng was admitted to the hospital a few years ago, people from the town and the villages around contributed money to pay for his wooden leg. Ching Huat refused to accept the money; he had wanted to pay for it himself. He had the money; he did not want to burden the people. But Lazim and Raman were adamant that they too wanted to help Yew Seng. The final decision was left to Yew Seng and he had chosen to accept a wooden leg contributed by the Malay, Indian and the Chinese communities. That was the wooden leg he still used.)

(Interlock, 2010:406)

Accounts such as this exemplify the experiences of a common history which is forced by circumstances which "produce certain common attitudes and traits, often called national character" (Kohn 1944:9). Shared experiences can inspire people to come together and make them feel that they belong together. Abdullah is asserting his view of the national character; he sees the nation as one which is coloured by different races from different cultures who can still live a harmonious life by helping each other. Hence, Interlok successfully portrays the novelist's intention to re-evaluate the construction of a nation through his depiction of race and conflict.

\section{Conclusion}

What does it mean to be a citizen of Malaysia? Farish Noor (2009) in his book noted that a nation must have its own literary culture that can bind the people of that nation together. Interlok presents to the audience an alternative view in the issue of nationalism and race relation. The novel requires the reader to be 


\section{MALAY LITERATURE}

attentive and critical in matters that are considered to be sensitive. In order to understand the messages embedded in the story, the reader must read the entire novel and understand the novel's main purpose. By paying attention to words deemed as "racist", many critics have failed to understand the spirit in which the novel is written. Interlok celebrates the diversity of races, and emphasises the importance of individual customs and norms in the process of building a young nation which had just witnessed its worst racial conflict in 1969. The original version of the novel encompasses the hope of the novelist of the unity of all Malaysians-"1Malaysia"-long before the slogan became fashionable.

\section{References}

Abdullah Hussain, 1971. Interlok. Kuala Lumpur: Dewan Bahasa dan Pustaka.

Abdullah Hussain, 2010. Interlok. Edisi Murid. Kuala Lumpur: Dewan Bahasa dan Pustaka.

Abdullah Hussain, 2010. Interlock. Translated by Azizah Hamzah \& Hashim Yaacob. Kuala Lumpur: Institut Terjemahan Negara Malaysia.

Abdullah, F., 2007. "Dasar Pendidikan Kebangsaan" in Y. Ismail, Dasar-Dasar

Utama Kerajaan Malaysia. Kuala Lumpur: Percetakan Zafar, 119-34.

Abraham, C. (2011, February 26). "Withdrawal of Interlok Mandatory".

Retrieved 8 March 2011, from http://malaysia-today.net/mtcolumns/ letterssurat/38391-withdrawal-of-interlok-mandatory.

Anthony, J. (2011, January 18). “Interlok: Scant Understanding Dangerous to

School Children". Retrieved 8 March 2011, from http://english.cpiasia.net/ index.php?

Arthur, J., 2007. Race, Equality and the Burdens of History. New York: Cambridge University Press.

Dzulkifli Abdul Razak. (2011, January 29). "Time for Majlis Profesor

Negara to Step In". Retrieved 8 March 2011, from http://www.nst.com.my/ nst/articles/mapff/Article.

Farish A. Noor, 2009. What Your Teacher Didn't Tell You: The Annexe Lectures (Vol. 1). Puchong: Matahari Books.

Feagin, J.R., Feagin, C.B., 1999. Racial and Ethnic Relations. 6th Edition. Missouri: Prentice Hall

Hartal MSM. (2011, February 22). "Interlok: Chinese sell their daughters".

Retrieved 8 March 2011, from http://www.malaysia-today.net/archives/ archives-2011/38301-interlok-chinese-sell-their-daughters. 
Hartal MSM. (2011, February 24). "Interlok: When The Indian Cries, Nobody Hears". Retrieved 8 March 2011, from http://www.malaysianmirror.com/ media-buzz-detail/4-letters/52131-interlok-when-the-indian-cries-nobodyhears.

Helmi Mohd. Foad. (2011, January 8). "100 Penduduk Bakar Interlok". Retrieved 8 March 2011, from http://www.utusan.com.my/utusan/info. asp? $=2011 \& d t=0108 \& p u b=u t u s a n \_$malaysia\&sec=Terkini $\& p g=b t \_26$. htm\&arc $=$ hive.

Johan Jaaffar. (2011, January 22). "Give a Fair Hearing to Abdullah's Interlok". Retrieved 8 March 2011, from http://www.nst.com.my/nst/ articles/17johan0121/Article/.

Kohn, H., 1944. The Idea of Nationalism: A Study in its Origins and Background. New Jersey: Transnational Publisher.

Malaysian Mirror. (2011, February 24). "Interlok: Chinese Assembly Hall Youth Section Speaks Out". Retrieved 8 March 2011, from http://www. malaysianmirror.com/media-buzz-detail/4-letters/52134-interlok-chineseassembly-hall-youth-section-speaks-out.

Pragalath, K. (2011, January 28). "Imperative that the Public Lock Horns over Interlok". Retrieved 8 March 2011, from http://english.cpiasia.net/index. php?option $=$ com_content\&view $=$ article\&id $=2129 \&$ catid $=222$.

Rajendran, N.S. (2011, January 20). "Interlok Controversy: Respect Our Rich Cultural Diversity". Retrieved 8 March 2011, from http://www.nst.com. my/nst/articles/19lock/Article/.

Suzieana Uda Nagu, Nurjehan Mohamed. (2011, January 22). "Issues: Interlok in Gridlock". Retrieved 8 March 2011, from http://www.nst.com.my/nst/ articles/Issues_Interlokingridlock/Article/.

The Malay Mail. (2011, February 15). "Nobody Should Issue Sensitive Statements before Interlok". Panel Meeting: Palanivel. Retrieved 8 March 2011, from http://mmail.com.my/content/63891-nobody-should-issue-sensitive-statements-interlok-panel-meeting-palanivel.

Thong, S. (2011). "Interlok: Chock Full of Insults Against Chinese Too (and Lots of Unsavoury Material)". Retrieved 8 March 2011, from http://scottthong.wordpress.com/2011/02/22/interlok-chockfull-of-insults-againstchinese-too/.

Utusan Online. (2011, January 12). "Dusta Jika Anggap Interlok Tidak Baik". Retrieved 8 March 2011, from http://www.utusan.com.my/utusan/info. asp? $=2011 \& \mathrm{dt}=0112 \& \mathrm{pub}=$ Utusan_Malaysia\&sec=Dalam\%5FNegeri\& $\mathrm{pg}=\mathrm{dn} \_06 . \mathrm{htm}$. 
MALAY LITERATURE

Utusan Online, (2011, January 12). "MCA Pertahan Interlok, Tiada Elemen Rasis". Retrieved 8 March 2011, from http://www.utusan. com.my/ utusan/info.asp?y=2011\&dt=0112\&pub=Utusan_Malaysia\&sec $=$ Dalam $\%$ 5FNegeri\&pg $=$ dn_ $07 . h t m$.

Wicks, P., 1980. "Education, British Colonialism, and a Plural Society in West Malaysia: The Development of Education in the British Settlements along the Straits of Malacca, 1786-1874" in History of Education Quarterly, Vol. 20, No. 2. 163 -87.

Zulkifli Jalil, (2011, January 12). "Rais: Biarkan Perenggan itu..." Retrieved 8 March 2011, from http://www.utusan.com.my/utusan/ info.asp? $\mathrm{y}=2011 \& \mathrm{dt}=0112 \& \mathrm{pub}=$ utusan_malaysia\&sec $=$ Dalam Negeri\&pg=dn_05.htm\&arc=hive. 